Meta

Journal des tradlucteurs

Translators' Journal

\title{
The Pedagogy of thème spécialisé
}

\section{Alan Manning}

Volume 33, numéro 2, juin 1988

L'enseignement de la traduction au Canada - Teaching Translation

in Canada

URI : https://id.erudit.org/iderudit/003551ar

DOI : https://doi.org/10.7202/003551ar

Aller au sommaire du numéro

Éditeur(s)

Les Presses de l'Université de Montréal

ISSN

0026-0452 (imprimé)

1492-1421 (numérique)

Découvrir la revue

Citer cet article

Manning, A. (1988). The Pedagogy of thème spécialisé. Meta, 33(2), 227-237.

https://doi.org/10.7202/003551ar d'utilisation que vous pouvez consulter en ligne.

https://apropos.erudit.org/fr/usagers/politique-dutilisation/ 


\title{
THE PEDAGOGY OF THEME SPÉCIALISÉ
}

\author{
ALAN MANNING \\ Université Laval, Québec, Québec
}

\section{INTRODUCTION}

Une autre linguistique dit que "la traduction consiste à produire dans la langue d'arrivée l'équivalent naturel le plus proche du message de la langue de départ, d'abord quant à la signification, puis quant au style ». Mais Georges Mounin remarque avec justesse que cet équivalent naturel le plus proche est rarement donné une fois pour toutes. Et il est vrai qu'on $n$ 'en a jamais fini, que chaque traducteur a souvent envie de recommencer les traductions des autres, et toujours de recommencer les siennes. (Aury, 1963 : xii)

"Meaning", "form" and "closest natural equivalent" are terms that have been and will continue to be the common stock of translation terminology and theoretical literature. It is also true that the translation process is, as it were, an "éternel recommencement" and that the practical constraints of the professional market hold this temptation in check. Furthermore, concepts and considerations such as these have long been an integral part of translation school programs in Canada and elswhere. However, insufficient attention seems to have been given to the pedagogical aspect of translation. The purpose of this article is to propose a pedagogy of one aspect of translation : that of Thème spécialisé in the translation program at Université Laval. It will then deal with the theoretical component of the course (the nature of translation, literary vs. nonliterary communication, a framework of linguistic analysis of texts, selection of texts, translation technique and methodology, the translator's resources, human and nonhuman, the translation workshop : its organization and goals). Finally, it will describe, by way of a sample text, the operationalisation of the theoretical component in the classroom setting (extratextual, intratextual, intertextual analyses, the practical component). In conclusion, the value of the pedagogy proposed will be assessed.

\subsection{THÈME SPÉCIALISÉ AND ITS PLACE IN THE LAVAL TRANSLATION PROGRAM}

The translation program at Laval is designed to train the student to translate into his native language, French, at a high level of proficiency within three years. During that period, he is also expected to develop a perfect comprehension of written English as well as to write correctly in that language. In the first year, the student takes two advanced English grammar courses with an introduction to general translation, in conjunction with a course in Anglo-American culture and civilization and text analysis. In the second year, he receives two terms of training in advanced general translation. In the third and final year, the student is grounded in specialized translation. In the first term of the third year, he takes Thème spécialisé, in the second, Thème approfondi. This article will focus on the pedagogy of Thème spécialisé. 


\section{THEORETICAL CONSIDERATIONS}

\subsection{THE NATURE OF TRANSLATION}

Everyone, whatever his chosen field of endeavour, should have a theory; that is a conceptual framework to express the belief or beliefs that explain and motivate one's action in a given area. Although this is a layman's definition of theory, there are a number of scientific theories of translation.

Some theorists of translation claim that translation is impossible ; for them translation is a betrayal of the original text. Others maintain that translation can and must be done in this technological age. This is our view. We should add that it is vital to have a systematized definition of translation to teach our future translators the tools of their chosen profession with maximum efficiency.

Jacques Flamand, a professional translator-revisor himself, has put forward the most recent and complete definition of the nature of translation to date : "Traduire, c'est rendre le message du texte de départ avec exactitude (fidélité à l'auteur) en une langue d'arrivée correcte, authentique et adaptée au sujet et à la destination (fidélité au destinataire)" (Flamand, 1983:25). The key notions of this definition can be summarized as follows :

1. Translation involves rendering not just the words or linguistic forms of the text, but the message - those elements that express the intentions of the writer ;

2. Translation requires that one observe the servitudes of the target language (orthography, abbreviations, grammar, idioms, etc.);

3. Translation should not sound like translation. It should read like a piece of original writing and so avoid over-literalness;

4. Translation should, where appropriate, read as if it had been written by an expert in the field.

The belief behind Flamand's definition is that a written text is a message and that every message has an intratextual aspect - the linguistic elements of the text, i.e. the text per se - and the extratextual aspect - the circumstances surrounding the production of the message, including the expectations and presuppositions of both writer and reader.

\subsection{LITERARY VS. NON-LITERARY COMMUNICATION : A DEFINITION}

The goal of Thème spécialisé is specialized translation. However, one cannot proceed to translate specialized texts without fully understanding what constitutes a specialized text. For example, literary translation may be said to be a branch of specialized translation. In short, some criteria must first be developed to distinguish literary from non-literary communication in general. Only then can one establish a further set of criteria to distinguish general from specialized communication. The purpose, therefore, of this section is to attempt a definition of literary vs. non-literary communication in terms of three criteria : topicality of subject-matter, social commitment and obligation and function of language. Once this step has been accomplished, the student will be equipped with the critical tools necessary to differentiate between other types of texts ; in particular, the differences between general and specialized texts. (see 2.4.3)

There are basically three ways, adapted from Ziegesar (1979), in which literary communication can be distinguished from non-literary communication :

1. Topicality. It is assumed that, in non-literary texts, references to people, places, times and events belong to the world of empirical reality at the time of writing. Not so in literary texts, which are not bound by constraints of time and are open to many interpretations. 
2. Social commitment and obligation. The writer is obliged to conform to a role allotted to him by society. As such, he is required to provide accurate information in a style that befits his role. Depending on the type of text (for example a car manual, an act of law), it is advisable for the reader to conform to a certain kind of behaviour. Nonobservance can result in injury to him or imprisonment. The writer and reader of a literary text are autonomous and distinet from the normal compound writer/reader and are not therefore subject to social constraints or norms.

3. Functions of language. A writer's intentions are manifested in a particular function of language. Karl Bühler postulated three functions of language : the informative, the expressive and the directive functions. All three functions are directly limited to the three main elements of a communication situation : the reader, the writer and the referents.

A text in which the emphasis is on the referents reflects the informative function (e.g. press releases, travel guides, scientific reports); $\mathbf{a}$ text in which the accent is on the writer reflects the expressive function (e.g. letters, diaries, editorials); a text in which the focus is on the reader corresponds to the directive function (e.g. instructions, advertisements, contracts).

In all three instances, the focus of the text is external, that is to the outside world of reality. Hence they are called 'pragmatic'. In contrast, the literary text is characterized by what Roman Jakobson termed the poetic function; this is one in which the orientation of the text is no longer to external reality but to itself.

Clearly, it would be difficult to maintain that a text is characterized by any single one of these functions. However, though several functions may be reflected in a given text, there is a tendency for one to predominate.

\subsection{A FRAMEWORK FOR THE ANALYSIS OF LINGUISTIC ELEMENTS OF THE TEXT}

It has just been established that the choice of linguistic elements in writing any text is conditioned by the situation in which the message takes place. Some framework is necessary in order to analyze those elements. The best framework put forward so far is that of D. and M. Ziegesar (1979: 8-9). In their model, the linguistic elements of a text are grouped under six headings, namely, graphology, morphology, semantics, phonology, syntax and composition. The pertinent linguistic features are listed under each heading. The Ziegesar model is described fully in the appendix to this article.

\section{PEdagogical Considerations}

\subsection{SELECTION OF TEXTS}

The texts for the course were selected according to two criteria :

1. The first criterion was that of register. Texts are marked as belonging to a particular register by a characteristic use of language. A written message may be identified with certain professions or fields such as law or science by typical linguistic conventions. Other messages may contain linguistic elements which tend to appear in one kind of text rather than another. We chose texts covering a variety of registers, from the formal to the less formal.

2. The second criterion was that of marketability. To the greatest degree possible, texts were chosen on the basis of their suitability for preparing the student for his career. For this reason, priority was given to non-literary texts, which, by and large, reflected the current needs and demands of Canada's translation market.

\subsection{TRANSLATION TECHNIQUE AND METHODOLOGY}

The translation process can be summarized in four steps (Flamand, $1983: 29-31$ ) : 
1. Assimilation or 'tuning'. This involves a thorough analysis and understanding of the text in all its aspects. The Ziegesar analytic model is a vital tool at this initial stage of the translation process. Furthermore, assimilation of the text necessitates memorizing not words but stretches of information - the longer those stretches of information, the better the translation is likely to be;

2. Conversion. This is the "professional" stage of the process, when the text is translated to the target language. It requires that the translator detach himself from the text and recast it in the other language at the highest possible degree of idiomaticity. It also entails that the translator possess a sound knowledge of the subject and he be thoroughly conversant with the subject and style of his text in the source and target languages.

3. Writing. Many problems occur at this stage. What was not a problem before may well become one now. This step can, but not always, occur at the conversion stage.

4. Checking. This involves three steps :

(i) Objective reading. Check the SL and TL for correctness, authenticity and register.

(ii) Critical reading. Check the TL for readibility and naturalness. At this stage, the text is typed and sent for revision.

(iii) Final reading. The product is read once more for final 'bugs' (spellers, wrong font, etc.) before being sent to the customer.

\subsection{THE TRANSLATOR'S RESOURCES, HUMAN AND NON-HUMAN}

The resources to which the translator must have access are of two types :

1. Human. The translator is expected to demonstrate :

- creativity

- imagination

- organization and method

- research ability

- punctuality.

Other human resources available to him comprise specialists, librarians and fellow translators.

2. Non-human.

- Bibliographies (esp. Delisle's Guide bibliographique du traducteur) ;

- Libraries (local, university, government) ;

- Terminology banks (BTQ, OLF, Secrétariat d'État);

- List of government agencies ;

- Materials : file cards, white-out, typewriter, paper, calender, contract files (in/ out, copies), receipts files (for tax purposes), dictionaries, encyclopaedias.

\subsection{THE TRANSLATION WORKSHOP : ORGANIZATION AND GOALS}

The course comprises fourteen workshops, each workshop lasting approximately three hours. The first hour is devoted to theoretical considerations surrounding the text assigned for translation. During the remainder of the period, the translation problems and difficulties encountered by the students are discussed and solutions are proposed.

\subsubsection{The Translation Workshop : The Theoritical Component}

The theoretical component of the workshop is subdivided under three headings, each identifying separate but interdependent approaches to the text : the extratextual analysis, the intratextual analysis and the intertextual analysis. In preparation for each workshop, the students are asked to bear in mind the methodologies and analytical techniques described in the introductory lecture to the class. 


\subsubsection{The Extratextual Analysis}

The extratextual analysis entails reconstructing the communication situation of the text and is carried out with four considerations in mind : the writer; the reader; the language function ; the medium (i.e. form). It is obvious that such an analysis cannot be done without some reference to the text itself.

\subsubsection{The Intratextual Analysis}

The intratextual analysis is conducted on the SL under the six headings suggested by Ziegesar. Below is a sample of the types of questions students might and should, in any event, be asking themselves. The questions relate to two scientific texts, one specialized, the other more popular i.e. targeted at the non-specialist reader. (The two texts deal with heart transplantation). They are taken from Vigner (1975-1976:28-29).

1. Graphology. How far does the layout suggest which readership the two texts were written for?

2. Morphology. Is there any stress on either the active or the passive voice and with what effect?

How does the writer maintain the impersonal tone, despite the mention of an agent ?

What is the difference in effect between the active and the passive voice in the two texts?

3. Semantics. How does the writer's choice of vocabulary suggest the style he is trying to achieve and his intentions as far as the reader is concerned?

How do the writers describe their referents (the people, events, places, etc., which they write about) ? Do they link them with certain words and associations? What is implied about the writers' attitudes to their subject matter and their intentions as far as the reader is concerned ?

4. Syntax. What does the average length of the sentences reveal about the writer's presuppositions as to his reader's reading habits?

5. Composition. Summarize the main steps in the composition of the text and describe how far it reflects both the writer's attitude to his subject matter and his intentions as far the reader is concerned.

The reader is referred to Vigner's article for possible answers to all these questions (1975-1976 : 30-32, 41-42).

\subsubsection{The Intertextual Analysis}

The intertextual analysis phase is devoted to analyzing and cataloguing, on the basis of as many equivalent target texts as possible, of the linguistic features and elements characteristic of the kind of text that is being translated. In other words, the students are learning how to develop a "sense" of text typology. With this in mind, they are invited to bring to class as many texts as possible that are representative of the style and subject matter of the text for translation. For example, a number of English articles from the bibliography of the specialized text, and several articles from Time concerning the recent heart implantations at the Humana Institute in the United States were presented and discussed during the workshop.

\subsubsection{The Translation Workshop : The Practical Component}

The practical component of the translation worshop is, as the term implies, devoted to the application of the three analytical phases described above, namely : the extratextual, the intratextual and the intertextual analyses. It is possible to conduct this stage of the workshop in two ways. The text may be tackled on a sentence by sentence, line by line basis. This approach is feasible and desirable when the translation passage is 
relatively short. Otherwise, the text can be approached from a selective point of view, that is, concentrating attention on those areas of the passage that present problems of significant difficulty for the average student. The selective method is desirable when the text is on the longer side. Naturally, texts are chosen both according to their practicality and marketability as well as on the basis of length, usually between 250 and 450 words, as well as to the possibility of translating them in the two-hour practical component of the workshop. The selective translation approach enables one to include interesting texts that could not be translated fully in the allotted time period.

As regards the teaching of the students, again the approach will depend on a number of factors, principally the length of the passage for translation and its difficulty. Hence, a translation of average length, around 250 words, of average difficulty, can be tackled by asking individual students, in chronological sequence, to dictate a sentence on the blackboard. The translation is then criticized and subsequently modified to bring it into line with established translation criteria. (See above : 1.1 The Nature of Translation.)

However, with the longer, more difficult texts, a group approach is to be recommended. At the beginning of the class, the chief problem areas of the text are identified. The class is then divided into groups, and each group is asked to "pool" its resources and work on a specific part of the text. The group designates a spokesman, who will explain how he and his peers arrived at its translation. The students are always encouraged to utilize as much as possible the theoretical notions outlined in the first part of the workshop.

\section{PRACTICAL CONSIDERATIONS}

\subsection{THE METHOD APPLIED}

It is now appropriate to provide an illustration of the proposed methodology, or pedagogy of Thème spécialisé. Space does not allow for more than one example, so that we have chosen a text that is of reasonable length and difficulty, which epitomizes the types of questions and problems raised throughout the course. The text is an extract from a catalogue of Québec traditional furniture exhibits, entitled le Trésor du grand siècle by Luc Noppen and René Villeneuve (Québec, 1984:31-32).

\subsection{THE TRANSLATION WORKSHOP : THE THEORETICAL COMPONENT}

Before beginning the analytic phases of the translation of the text, a summary of the translation problems associated with the passage translated at the previous week's workshop was provided. That class dealt with letters of application. The primary function of the letter of application was shown to be informative, and the major translation problems encountered were related to morphorlogy (tenses, pronouns), semantics (terminology), syntax (linear structure) and composition (the structure of this kind of letter in English tends to be tripartite). The text to be dealt with during this class also reflected informative function chiefly, but the intertextual problems were shown to be different given the subject matter and text type.

\subsection{THE EXTRATEXTUAL ANALYSIS}

The extratextual analysis covers four aspects : the pragmatic aspect ; the writer ; the reader; and the text function.

\section{(a) The Pragmatic Aspect}

Many people from a wide range of backgrounds (specialists, non-specialists, etc.) will have to deal with this text. Hence, it has a great educational and communicative value. A large number of such texts are written in the province of Québec, and there is a 
constant demand for them to be translated into English in order to meet the needs of tourists and visitors from English Canada, the United States and elsewhere.

(b) The Writer

The texts are written by two authors. They are constrained by the catalogue form as well as spatial limitations. Their presence is extremely discreet, a fact that is noteworthy with respect to text type and function.

\section{(c) The Reader}

The basic appeal of the catalogue piece is to the average non-specialist reader. The reader has to be informed. Structure must therefore be clear and unambiguous. Terminology must be accurate and correlate exactly with what is depicted. The more specialized reader also has to be constrained, hence another reason for insisting on the proper term and on using the right term and on using the right source.

\section{(d) The Text Function}

The text reflects informative function primarily, since the focus is on the delivery of new facts and data. There are two very minor functions : an expressive function, revealing the writers' attitude or feelings towards their subject matter (cf. "aurait appartenu", "la chose est vraisemblable", "semble-t-il"); and a directive function, revealing the writers' desire to ease reading for their audience by explicating the logical developments in the text ("d'autant plus que", "donc").

\subsection{THE INTRATEXTUAL ANALYSIS}

The intratextual analysis phase focuses on four types of linguistic elements ; namely the morphology, semantics, syntax and composition of the text. These four aspects were highlighted, since they generally engender problems in the translation of such a text into English. We therefore decided to combine the intratextual and the intertextual analyses phases to facilitate teaching.

\section{(a) Morphology}

Whereas the present tense tends to predominate in the French text, specifically in the second and third paragraphs, in an equivalent English text there is a tendency for tenses to be distributed according to aspect. For example, in paragraph one (history of ownership), the French simple past/simple present combination corresponds in English to a simple past/present perfect alternation. In paragraph two (original social function of the desk), the simple present in French will be replaced in English by the simple past. In paragraph three (architectural style), the simple present in French corresponds to the simple present in English.

\section{(b) Semantics}

The semantic problems likely to be encountered in translating texts of this type can be classified into three groups : terminology, synonymy and idiom. Terminology subdivides into three kinds : institutions and titles ("Hôpital général de Québec", "Mgr de Saint-Vallier"), artistic ("l'écrit") and technical ("bureau à piètement tourné ", "tourné à balustres", etc.).

Synonymic reference in English is more concrete and explicit. For example, "la chose" becomes "the story" ; the implicit reference "institution" to the Hôpital général de Québec is translated as "hospital".

The idioms in this text type tend to be of three kinds : collocational : the pair "vécu/mort" sounds facetious translated literally into English and it is better in the context to replace "lived" by "remained". The second involves lexical gaps : "noblesse de robe/noblesse d'épée". These have to be expanded in English to convey their full meaning. The third kind relates to extension of usage in French and English. Such problems 
can be more structural ("selon la tradition qui prévaut") or simply lexical ("appartient", "s'inscrit dans une veine", "tâche", "autorité ", "se populariser").

(c) Syntax

Sentence length and structure must be subordinate to clear and unambiguous delivery of message. Consequently, when translating, it is advisable to distinguish between main ideas and express each one in a separate sentence. For example, in the first sentence of paragraph one, clarity of meaning dictates that the "retirement/death" episode of Mgr de Saint-Vallier be translated independently of the first part of the sentence. Similarly, repetition and redundancy should be eliminated by compressing or omitting those elements that are not strictly necessary to the transportation of the message. For example, in paragraph two, "type" can be deleted, and the phrase "parmi les aristocrates" - typical case of subordination in French from emphasis - can be effectively integrated into the structure of the main clause without loss of meaning. In addition, elements can be omitted without distorting the text, while enhancing the text's internal cohesion (cf. "le bureau est un meuble"). Sentences can be expanded to avoid ambiguity (cf. "sous le règne de ce ministre") and reversed to bring out meaning more completely (cf. "qui utilisent l'écrit pour accomplir leur tâche ou affirmer leur autorité ").

Consistent with both the text's style and function, where the focus is on imparting information and not on persuading (directive function), and the spatial constraints of the form there are few connectors. This facet of the text's syntactic character should be respected in English.

\section{(d) Composition}

The composition of a catalogue exhibit text is generally dictated by convention. The characteristics of the exhibit are summarized at the head of the description. The description itself is divided into three separate parts. Each part indicates a particular aspect of the exibit piece. Part one discusses the history of the piece's owners. Part two characterizes its sociological value. Part three provides a technical description of the exhibit. It is interesting to note that social and technical aspects of architecture are considered by architectural historians to be separate disciplines. The genres are therefore never mixed. The exhibit description transgresses this rule, but still maintains the distinction by means of individual paragraphing. It is important for the translator to bear these considerations in mind, particularly when checking for terminology and style.

\subsection{THE TRANSLATION WORKSHOP : DISCUSSION OF TRANSLATION}

Given the relatively short length of the text, students were called on individually to read out their translations, which were copied on the blackboard. Using their comments and suggestions, and with our own interventions wherever necessary, a fair translation was developed. At the end of the period, we summarized and classified the problems that presented the most difficulties. Those problems were recorded, along with the text's function, so that they could be compared with the corresponding data for other translation work done during the term. At the end of the course, all the data was tabulated and compared and a draft text typology established. Below is a tabulation of the major translation difficulties encountered in the translation of the catalogue exhibit text.

(a) Morphology

- "aurait appartenu" (2) : implies indirect speech in English i.e. Tradition has it (= It is traditionally said that...) that ... Therefore, translated by simple past. distancing).

- "ce" (1) : proximity of exhibit to speaker requires deictic this (vs. that : implies

- "deuxième évêque" (2) : the phrase is titular, therefore in English the definite article is required. 
- "conserve" (5) : implication in French is that the desk is still preserved at the Hôpital général". Hence, the present-perfect is required in English.

- "il" (13) : cohesion requires lexical repetition in English i.e. desk. Not necessary to repeat deictic "this". Reference to an object already clearly identified can be made using a definite article.

— "les aristocrates ... les intellectuels" (9) : reformulation leads to grammatical change, i.e. "intellectual aristocracy". popular".

- "se popularisa" (13) : grammatical change imposed by TL, i.e. "became

(b) Semantics

- "Selon la tradition qui prévaut..." (1) : idiom which requires translation by an equivalent phrase i.e. "Tradition has it that ...". The translation of the rest of the sentence will reflect the structural change within the idiom in English.

- "meuble" (2) : convention prefers repetition of the technical term given to this article in the summary at the head of the description. No need to repeat the whole syntagm ("writing desk"), but just the operative word in it.

- "institution" : "institution" would sound derogatory in English (a potential "faux-ami" !). The "institution" is in fact a hospital and it would be cohesively preferable to use this explicit, unambiguous term.

- "La chose" (4) : there is a preference in "informative" texts to choose the explicit term. Hence, "The story" would be more plausible here.

— "Vraisemblable" (4) : "Very likely" is preferable here to "possible" as it sounds more confident and less ambiguous.

- "est à l'usage" (7) : the implied meaning here is that of distinction. It is stylistically appropriate to make this idea quite clear in English i.e. "reserved". (Students should be reminded at this point of English's preference for the past tense in this text type when referring to the social history of the furniture piece.)

- "accomplir leur tâche" : "Task" in English would refer to some punctual activity. The reference here is to some formal set of responsibilities. Hence "execute their responsibilities", where the verb "execute" conveys the formal tone.

- "la noblesse de robe/la noblesse d'épée" : in more specialized writing, these terms could and usually are left untranslated. At a less formal level, they leave lexical gaps and must be translated to bring out their meaning. Hence, the "nobleman who lived by the pen from the nobleman who lived by the sword".

- "sous le règne" (12) : the problem here stems from the confusion in the French text. "Règne" would normally belong logically to "Anne d'Autriche". The solution is to find the phrase that collocates with "ministre", i.e. "when this minister was in power".

- "s'inscrit dans une veine..." : the French is pompous and unclear. "S'inscrire" when preceded by an inanimate, non-human subject always provides the translator with a problem. It is best translated according to context, i.e. "which are more architectural than...".

\section{(c) Syntax}

- "conserve d'autres meubles" (5) : The syntax is reserved in English to highlight the real topic of the sentence : "other furniture". The link between the first and the second sentences in the French text is strictly "meuble" (2) and "meubles" (5).

- "qui utilisent ... autorité " (7-8) : The logical solution in English would be linear, i.e. describe the means first and the end second. However, the real topic of the sentence is "the written word" which must be placed in a position of emphasis, here at the end. Hence the syntactic reversal. Note the reversal of the verb phrases in English : "exercised their authority or executed their responsibilities". In English, style dictates that, 
unless there is a distortion of meaning, the longer phrase(s) be placed last in the sequence.

"semble-t-il" (12) : the adverbial properly belongs next to the phrase that it modifies. Hence, it has been placed in its grammatical position as a sentence adverb between the subject and before the verb phrase "became popular".

— "mais" (13) : "Although" is preferred when "but" is followed by a relative clause ("which are more...").

\subsection{TABULATION OF TRANSLATION PROBLEMS}

At the end of the class the students tabulated the function(s) and problem areas as follows : the text reflects informative function, but with two minor expressive and directive functions. The major translation problems were found to be morphological and syntactic.

\section{CONCLUSION}

The advantages of the approach outlined in this article are several. It bridges the gap between the classroom and the real world of translation by focussing on "marketable" texts. Likewise, it prepares the student for the professional environment of translation by introducing him or her to the practice of teamwork - professional translators consult each other all the time about their work and it is important to know what constitutes consultation and how it is best carried out so that it is a constructive exercise for all parties involved. But, above all, the approach provides the future translator with a rational framework within which to develop further his aptitudes and competence in specialized translation. On the one hand, it familiarizes him with a set of theoretical criteria and notions - language functions and discourse - to analyze and understand different types of texts in French and English. On the other, he is trained in a practical methodology that makes it possible to exploit those criteria and notions effectively. In short, the course's aim is to teach the student to understand how and why he is translating in a particular way in a particular context. In fact, the theoretical component of Thème spécialisé is an invaluable complement to the practical aspect of the training of the future translator - one that is often neglected in undergraduate courses in specialized translation. Such a component is also important in that it gives a theoretical base to those students who wish to continue and do graduate work in the field. Finally, it is a reminder that translation is as much an academic, as it is a professional discipline, and that the academic and professional worlds are paradoxically independent yet complementary.

\section{BIBLIOGRAPHY}

AURY, Dominique (1963) : "Préface" in Mounin, Georges, les Problèmes théoriques de la traduction, Paris, Gallimard.

FLAMAND, Jacques (1983) : Écrire et traduire : sur la voie de la création, Ottawa, Éditions du Vermillon. NOPPEN, Luc et René VILLENEUVE (1984) : le Trésor du grand siècle, Musée de Québec, Québec.

VIGNER, Gérard (1975-1976) : "L'initiation à l'expression écrite dans les langues de spécialité. L'objectivation", le Français dans le monde, vol. 122: 26-32, 41-42.

ZIEGESAR, Detlef and Margaret (1979). How to Analyse and Teach Non-Literary Texts, Königstein, Scriptor. 


\section{APPENDIX I}

Analysis of linguistic elements

Graphological Level

spelling

punctuation

capitalization

typographical layout

length of lines

spacing

paragraphing

Morphological Level

word-classes and their respective distribution

distribution of active and passive voice

tense and aspect

word formation

Semantic Level

choice of vocabulary

denotative and connotative meaning

personal pronouns

semantic figures of speech (similes, metaphors, etc.)

Phonological Level

phonological rhetorical devices (rhyme, rhythm, alliteration, onomatopoeia, etc.)

Syntactic Level

word order

types of sentences

length of sentences

linking of sentences

syntactic rhetorical devices (parallelism, repetition, etc.)

\section{Compository Level}

type of introduction

sequence forms (cataphoric, anaphoric, etc.)

text structuring (parallelism, climactic development, contrast, etc.)

text units (paragraphs, sections)

type of conclusion 